\title{
Incumbent Strategy of Nurdin Abdullah in Maintaining Power in Bantaeng
}

\author{
M Haboddin', L O M Afala ${ }^{2}$ \\ ${ }^{1,2}$ Universitas Brawijaya, Indonesia \\ ${ }^{1}$ muhtar_haboddin@ub.ac.id, ${ }^{2}$ machdani@ub.ac.id
}

\begin{abstract}
This article aims to explain Nurdin Abdullah's strategy in maintaining his power as a regional head in Bantaeng Regency, South Sulawesi. It is certainly not easy in the era of the direct election of the regional head. Some regional heads as an incumbent lost in the contestation. However, Abdullah is a thriving regional head that can maintain his authority for two terms in Banteng Regency. In its analysis, this article uses an actor-based approach by placing Abdullah as a rational actor who maintains his power in leading local government. The findings explain that populist policies, closesness and pro-community interest, and regional progress of Bantaeng as a result of real work that are in line with prosperity are the primary resources in maintaining his power in the second term. It not only has strengthened his social status and honor, but also his nobility as the true leader or traditional elite at the local community level.
\end{abstract}

Keywords: populist policy, regional progress, local politics, incumbent, Bantaeng

\section{INTRODUCTION}

The incumbent is a politically stronger and more powerful candidate than the challengers [1]. The incumbent figure demonstrated in this article is Nurdin Abdullah, who was elected two periods as regional head in Bantaeng Regency in 2008-2013 and 2013-2018. Specifically, the article reveals Abdullah's political strategy in maintaining power as a regional head of Bantaeng in the second term. Abdullah was the regent of Bantaeng, who comes from a traditional elite and is a nobleman who seizes and maintains his power for two terms. The ability to maintaining power shows that a nobleman is a superior actor in leading a region.

During the first five years (2008-2013) as a regional head, the development progress in Bantaeng was very rapid when compared to the surrounding area. Several populist policies that were always in direct contact with people's lives had become essential milestones in his administration. The success in maintaining power for two periods has raised the image of nobility as a great leader in advancing Bantaeng. It becomes a consideration for the community to re-elect him back so that Bantaeng would advance further. In general, the article discusses an incumbent elite of Abdullah in maintaining power at the local level. There have been many works of literature talking about the issue. However, it is still vague to explain new political phenomena like Abdullah.

In a political study, an incumbent is the regional ruling head who then runs for the next period. This incumbent is always portrayed as a strong figure who can win the elections. According to Eriyanto, the regional head has a considerable chance of winning the election [2]. For instance, in the election of 2006, as many as 62.2 percent of incumbent regional heads who advanced in the elections have succeeded in winning. Moreover, Eriyanto explained that the 
incumbent victory factor is because of two things, namely, popularity and using the APBD (Local Government Budget) as a form of concern for the community.

The popularity and utilization of the regional budget are still believed to be a factor of incumbent victory in the elections, but in practice, it is not always true. For instance, it can be seen in Jokowi-Ahok's victory in the DKI Jakarta election in which they defeated the incumbent couple of Fauzi Bowo-Nacrowi Ramli (Foke-Nara) who during the election process were favored by people based on many observers and survey institutions [3]. However, the popularity and utilization of the APBD apparently cannot win the incumbent pair, as seen in the Jakarta election. This was a surprise for the incumbent who only relied on the popularity and use of ABPD. From the Foke-Nara case, it seems that voters have authority in determining their leaders.

However, some observers still believe that the incumbent's victory is determined because of its popularity. According to Purwoko, he said that the incumbent could be re-elected because of popularity exposed by the mass media for all its activities, getting support from the regional bureaucracy, and work performance while leading [4]. The similar point between Purwoko and Eriyanto is on the popularity factor, and the rest complement each other in explaining the incumbent's electability in the direct local election. Conversely, a slightly different opinion is expressed by Haboddin that the incumbent could maintain power for two reasons; namely, the leadership is earned by the community, and work well, so that people's expectations of him can be realized [5].

From those explanations, many factors can deliver the incumbent to regain power. Those factors are popularity, budget utilization, bureaucratic support, and good work. Those refer to Purwoko's argument that the incumbent candidates are certainly on paper occupying the most superior position in the electoral contestation. It is very different from Umaya' argument that the winning of incumbent is due to three things [6]; firstly, the incumbent can do a coalition with the winning party in the election; secondly, the incumbent figure has the resources to use it to win again; and thirdly, the incumbent is successful in developing the region. Such success factors are essential factors to explain the strategy of Abdullah in maintaining and achieving power at the local level.

\section{RESEARCH METHOD}

This study uses a case study as a research method. The choice of case studies is because the case examined is limited to individuals. In this regard, an individual or actor allows researchers to gain in-depth knowledge and understanding of the object, understudying about Abdullah's strategy in maintaining power [7]. In collecting data, there are two methods; namely, the first is through the study of literature that has relevance to this theme, and the second is through interviews with actors who have the knowledge and information capacity of Abdullah. In its analysis, this article synthesizes by looking for links between one and another category [8] in obtaining valid information about Abdullah's struggle to maintain power as a regional head. It is started by mapping and category of some popular policies of Abdullah and analyzing the impact of those policies on society. The last step is by explaining the policies' effect that is invested and reproduced in political contestation in gaining voters.

\section{RESULTS AND DISCUSSION}

\subsection{Three Strategies in Maintaining Power}




\subsubsection{Populist Policies}

The populist policy is the most rational choice for regional heads who do not have strong political power or support in the regional parliament (DPRD) to maintain power. Abdullah is one of the regional leaders elected as regional heads using the strategy. He did not have the support of non-parliamentary political parties (DPRD Bantaeng). Since the first term of his administration, he introduced some popular policies, particularly in the education and health sectors. By that, he purposed to improve the Bantaeng society of education and health.

In the field of education, Abdullah had long provided scholarships to the Bantaeng society. Under his administration, the education sector continued to improve anytime. Education has been free, and now all people can enjoy education equally. The efforts to advance his citizen in the field of education is not only for primary schools and further education but also for the construction of Early Childhood Education schools (PAUD). The PAUD is established through the program of the one village one PAUD. The person in charge of PAUD was Liestiaty, Abdullah's wife. Liestiaty was inaugurated as Mother of PAUD in Bantaeng District [9]. PAUD received the first prize at the provincial level. This is evidence of the commitment of Abdullah's leadership in advancing education in Bantaeng.

Besides, Abdullah also reformed health services for the community. Bantaeng community is very spoiled by health facilities. It is because he is very concerned about how to make the people of Bantaeng healthy. Moreover, he also built an international hospital (interview, 7/18/2017). For him, there should be no sick people. Therefore, the rights of the Bantaeng community must be considered (Interview, 31/10/2018). This shows the political commitment of regional heads to their people. In the Majalah Parlemen report, it is written as follows [10];

Salah satu inovasi bupati Bantaeng dalam bidang kesehatan adalah
pembentukan Brigade Siaga Bencana (BSB). Unit layanan kesehatan ini
melakukan kegiatan terpadu layanan kesehatan gratis dengan melibatkan 20
dokter, delapan perawat, di tunjang mobil ambulans. Kunci sukses BSB adalah
bergerak tanpa dipungut biaya dari masyarakat. BSB bergerak kesasaran,
cukup dengan menelpon ke-113. Ketika tiba di tempat yang di tuju, petugas
melakukan observasi kepada pasien. Bila petugas bisa menangani di tempat,
maka tidak perlu diantar ke rumah sakit. Namun, bila kondisinya memerlukan
perawatan lebih lanjut, ambulans akan membawa pasien ke rumah sakit.

The above quote proves how Abdullah spoiled his citizens in the health field. The service is excellent because patients can be picked up at the support location with professional media staff. Health services were also free. This was the advantage of health services in Bantaeng. The success in the field of health made Bantaeng crowned a healthy district by the Minister of Health of the Republic of Indonesia.

Public services in the education and health sectors are truly very pro-community. This service was intentionally encouraged by Abdullah because he wanted to provide convenient services to the people of Bantaeng (Interview, 31/10/2018). Education and health services were populist policies because they were fundamental needs and directly in contact with the needs of the lower classes. With the populist policies, Abdullah indirectly built political support at the mass level. It becomes a political investment or political resource for Abdullah in maintaining and reseizing power in the second term of Banteng administration. 


\subsubsection{Regional Development}

Abdullah not only built and maintain his power through populist policies but also carried out regional development programs. Through the programs, there have brought many changes in society. Previously, Bantaeng was not widely popular, if anyone knows, the are was identic with underdevelopment and poverty. This negative image is slowly but surely changed through development programs. Abdullah conjured Bantaeng as reported by Majalah Parlemen as follows [10]:

Tidak banyak Bupati di negeri ini yang mampu melakukan barbagai inovasi untuk membangun daerah yang dipimpinnya menjadi maju. Hanya mereka yang memiliki keinginan, komitmen yang kuat, kerja keras, dan niat yang tulus bagi kesejahteraan rakyatnya yang dapat mewujudkannya. di bawah kepemimpinan Nurdin Abdullah banyak orang tercengang melihat kemajuan yang dicapai. Wilayah Bantaeng yang tidak luas, dengan penduduk 180.000 juta jiwa, dan potensi alamnya yang pas-pasan, tapi infrastruktur terbangun dimana-mana dan aktivitas ekonomi masyarakat berjalan lancar.

In a similar vein, Haryanto and Rosyidin [11] in his book entitled Sepuluh Tokoh Transformatif Indonesia writes:

Dalam melakukan pembangunan daerah Nurdin Abdullah mengembangkan tiga klaster yang sesuai dengan karakteristik dan potensi daerah Bantaeng, yakni pegunungan, dataran, dan pantai. Tiga klaster ini dikembangkan secara besarbesaran. Pembangunan infrastruktur di lakukan dari dataran rendah titik 0 hingga mencapai wilayah pengunungan yang berada di ketinggian 1.300 di bawah permukaan laut. Tujuan utamanya tentu saja untuk meningkatkan kesejahteraan masyarakat Bantaeng.

Development progress not only excites community economic activities but also increases community welfare. This is an essential point of development progress in which Increased development has an impact on welfare. Community welfare is one of mission under Abdullah's administration. The mission is in line with the purpose of decentralization aimed at welfare. Bantaeng, known as a small and poor area, has been changed in providing welfare to its citizens. It can be done because Abdullah had two concerns, namely, firstly, he favors the interests of the poor, and secondly, the government involves the community in regional development programs [12].

Through development programs which involved the community has impacted on regional progress. Bantaeng developed into a front runner in regional development. The growth rate of Bantaeng's development is extraordinary. Syamsul said that development in Bantaeng was very even (interview, 2/11/2018). The sea, urban, and mountain zones are arranged and improved well. In the axis region-urban, the development is extraordinary. Bantaeng development experienced very rapid growth. Bantaeng is a highly developed Southern region. Under the leadership of Abdullah, Bantaeng was easy to organize and build. He got much funding from the central government used to support development programs in Bantaeng.

\subsubsection{Siding with the people}

Another strategy explaining why Abdullah can maintain his power in the second term is that he was more concern about people's interests than the elite. Abdullah is well aware that the 
strength and support of the community are far more important than the support of politicians in the local legislative assembly (DPRD). In the direct election system, the people are the determinant. Therefore, it is very logical that all real work and achievements are solely aimed at the people of Bantaeng. Abdullah understood very well that what he was doing was not "imaging politics, but real work." Of course, Abdullah wanted to give a signal that a regional leader must work and work. The most tangible work result was when Abdullah made several pro-people policies. The pro-people policies were Abdullah's strategy to develop his hometown. Those policies can penetrate the community, both individual, group, and public. For more details, it can be seen in table 1 as follow.

\begin{tabular}{l|ll}
\multicolumn{2}{c}{ Objection } & \multicolumn{2}{|c}{$\begin{array}{l}\text { Table 1. Objection and Forms of Policies } \\
\text { Individual }\end{array}$} & $\bullet$ & $\begin{array}{l}\text { Provision of work } \\
\text { Providing Bidik Misi medical scholarships at Unhas; }\end{array}$ \\
& $\bullet$ & $\begin{array}{l}\text { Other social assistance, such as circumcision, marriage, } \\
\text { death, etc. }\end{array}$ \\
\hline \multirow{3}{*}{ Group } & $\bullet$ & BUMDes Funds \\
& $\bullet$ & Comparative study of agriculture to Malang \\
\hline \multirow{2}{*}{ Public } & $\bullet$ & Doctor internship in Japan \\
& $\bullet$ & $\begin{array}{l}\text { Education } \\
\text { Health }\end{array}$ \\
& $\bullet$ & Administrative services
\end{tabular}

Those policy programs used regional government facilities and regional budget funds for the people's welfare. The policies were very nuanced in popular. Its policy targets also vary greatly, from an individual group to the public. On an individual level, Abdullah helped his citizens by providing work. The work could be recommended working in a company in Bantaeng or given business assistance. In addition, Abdullah also provided Bidik Misi scholarship to students and other social assistance to the people who need help. This social policy rests on a local value called pacce '(poignant).

Pacce' secara harafiah bermakna perasaan pedih dan perih yang dirasakan meresap dalam kalbu seseorang, karena melihat penderitaan orang lain. Pacce' berfungsi sebagai alat penggalang solidaritas, kebersamaan, kesetiaan, rasa kemanusiaan, dan motivasi untuk berusaha, sekalipun dalam keadaan sangat pelik dan sulit [13].

Abdullah can be described as someone who really cares about his people. This more personal social policy really helps the people who need it. For the people of Bantaeng, Abdullah is very well known as a noble and generous leader who likes to help others. People have long felt the generosity of Abdullah. Before becoming the regional head, many Bantaeng people have been helped by him. The people helped are very grateful to him (interview, 10/10/2018). This social philanthropy is a part of strengthening character and power at the community level.

In addition, Abdullah also made policies intended for groups. For instance, he gave funds to the community for the establishment of BUMDES (Village Owned Enterprises). The funds provided are intended to encourage the village economy so that the village is more developed and prosperous. Nurdin's partisanship to the village not only provided financial assistance and increased village authority, but some of the farmers were also trained in Malang Regency and Batu City. The result of training is awesome as Tempo Magazine writes as follows [14]: 
Di Bantaeng, hiduplah kelompok-kelompok petani yang berhasil membebaskan daerahnya dari kemiskinan panjang, serta jeratan para rentenir, dan tengkulak. Terobosan itu bermula sejak tahun 2008, takala BUMDES dibentuk di seluruh kabupaten Bantaeng untuk membantu petani. Mereka dipandu mengenali tanah lebih dekat, sehingga lahan tandus pun bisa diolah menjadi sumber ekonomi. Penghargaan datang silih berganti hingga ke tingkat nasional. Akhir Juni tahun 2012, Bantaeng menerima kembali penghargaan. Otak dibalik keberhasilan tersebut adalah Nurdin Abdullah.

Moreover, Bantaeng doctors were sent to Japan to do an internship. The purpose is that the doctors can get more skilled in carrying out their duties. For Abdullah, doctors need to be strengthened not only in hard skills but also in soft skills so they can be a professional who would work in Bantaeng Hospital. In short, hospitals need skilled workers who can address the needs of the community and respond to the demands of global competition [9].

The following policy is public, meaning all Bantaeng residents can enjoy this policy. Abdullah's efforts were to improve health services through the construction of an eight-story hospital, improvement of facilities, and the addition of doctors and paramedics. In the field of education, the continuous improvement was also carried out. In administrative services, the improvement is also carried out because the Bantaeng bureaucracy was demanded to be friendly in service and to provide services to the community.

In short, Abdullah has provided innovative policies and has been very pro-community. All of the policies listed in table 1 were very successful because the benefits of the Bantaeng community are felt. This can happen because the Regent develops policy in favor of the people of Bantaeng as a whole [10]. In line with that, Abdullah said the current leader is demanded to work whose work can benefit the people. People no longer need leaders who show a beautiful appearance because the people are smart now, and they only support the work that gives only the results [11].

\subsection{The Great Leadership}

Real work and the results felt by the people of Bantaeng made Abdullah's name soar. Local leaders are someone who can work for people's interest. That was the impression Abdullah wanted to convey to the public and the Bantaeng community in particular. As a Karaeng, Abdullah tried hard to build a competent bureaucracy and accelerated development in Bantaeng. The bureaucracy that has been imaged slow, convoluted, and less responsive, has been changed to be more responsive and professional. Nurdin encouraged them to be active; they did not only sit and wait but also were pro-active to serve people [15]. In Abdullah's interview in Flamma Magazine said that [16]:

Saya terapkan disiplin kepada birokrat dan terus diingatkan secara konsisten tentang visi untuk bekerja kepada rakyat. Jadi, dalam satu tahun pertama saya minta para birokrat melihat bagaimana saya bekerja. Saya memberi teladan lalu birokrat mengikuti cara kerja saya. Awalnya memang sulit, tetapi ketika sudah terbentuk, semuanya menjadi mudah.

The quote above informs the importance of a leader's work. Abdullah tried to practice how a leader works and sets an example for his subordinates. After that, he asked for the bureaucrats to follow the workings. Aside from providing work standards, he also applied discipline to bureaucrats. Likewise, he tried to be a role model for his subordinates. For him, 
building Bantaeng cannot be done alone, because it requires local bureaucrats who are handle, committed, and have competence in helping execute local government programs.

Therefore, Abdullah is considered as a leader who works and inspires his apparatus. Inspiring leaders can move the people around them in building Bantaeng [17]. The result was that Abdullah and his team gradually improved the situation of Bantaeng. APBD (local government budget allocation) was absorbed well. He built Bantaeng from the Village and attracted the investors to advance the Bantaeng. In doing so, people appreciate and support his policies in advancing Bantaeng [18]. Now, people can see what Abdullah has been done and promised to them in his period.

\section{CONCLUSIONS}

In short, an incumbent maintaining power requires some strategies and exceptional leadership. In Banteng administration, by enacting populist policies, Abdullah made a breakthrough and innovation in public services such as education, health service, and regional development. Bantaeng was poor with low PAD (local government income), but under his administration, the regional development of Bantaeng increased significantly, and the people are more prosperous than previously. The lively regional development has made Bantaeng the fastest progress area and have also increased the Human Development Index (HDI).

Abdullah has succeeded in presenting the good government as a regent of Bantaeng. Local government was built-in understanding as solutions to the community so that performance and achievements while leading Bantaeng get positive recognition and evaluation. It is supported by Abdullah's leadership that is hard work, commitment, and partisanship in order to meet the needs of the community. Those brought Abdullah as the regional head for the second term. Therefore, as an incumbent, he is well known as a great regional leader.

\section{REFERENCES}

[1] P. A. LaVenia Jr, "Breaking the Iron Law: Robert Michels, The Rise of the Mass Party, and the Debate over Democracy and Oligarchy." State University of New York at Albany, 2011.

[2] Eriyanto, "Incumbent dan Pilkada'," LSI Kaji. Bln., no. 02 (Juni).

[3] D. Ambardi, "Pemilihan Gubernur DKI: Referendum untuk Foke?," Majalah Tempo.

[4] B. Purwoko, Demokrasi Mencari Bentuk. Yogyakarta: Plod dan JIPP, 2006.

[5] M. Haboddin, Ketika Mahasiswa Bicara Pilkada. Malang: UB Press, 2017.

[6] F. Umaya, "Incumbent dan Peta Politik Kota Jogjakarta," Kedaulatan Rakyat, 28-Apr2006.

[7] L. C. Johnson, Ilmu Politik dalam Paradigma Abad ke-21. Yogyakarta: Kencana, 2013.

[8] J. M. Lexy, Metode Penelitian Kualitatif Edisi Revisi. 2004.

[9] Fahruddin, Nurdin Abdullah: Act Locally, Think Globally. Jakarta: Naura, 2017.

[10] M. Parlemen, "Kesejahteraan Rakyat," 2011.

[11] G. G. Haryanto and I. Rosyidin, Sepuluh Tokoh Transformatif Indonesia. Jakarta: Erlangga, 2015.

[12] S. Eko, “'Dari Daerah Budiman Menuju Daerah Sejahtera',' J. Mandat., vol. 3, 2007.

[13] A. Z. Abidin, Persepsi Orang Bugis, Makassar Tentang Hukum, Negara, dan Dunia Luar. Bandung: Alumni, 1983.

[14] M. Tempo, "Yang Makmur ditanah Tandus," Majalah Tempo, 22, 2012.

[15] K. Robinso, Tapak-Tapak Waktu. Makassar: Ininnawa, 2005. 
[16] M. Flamma, "Pemerintah Yang Bekerja Untuk Rakyat," 2012.

[17] S. Palupi, "Pemimpin Parasit," Kompas, 22-Nov-2006.

[18] D. Syah, H. Cangara, and M. I. Sultan, "Opini dan Sikap Masyarakat terhadap Pembaharuan dan Kepemimpinan Bupati Nurdin Abdullah dalam Memajukan Bantaeng sebagai Kota Industri dan Wisata," KAREBA J. Ilmu Komun., vol. 4, no. 3, pp. 300314, 2016. 